Medieval Studies, vol. 22, 2018 / Studia z Dziejów Średniowiecza, tom 22, 2018

\author{
Patrik Pastrnak \\ (Oxford University) \\ https://orcid.org/0000-0002-9328-3219
}

\title{
Adducimus gemmam et florem: Bona Sforza's bridal journey (1518) in the light of rituals and ceremonies
}

Keywords: Sigismund I the Old, Bona Sforza, ceremonies, journey, Kraków

The wedding of Sigismund I the Old (1467-1548) and his second wife Bona Sforza (1494-1557) in 1517-1518 is one of the best-known and most closely examined Renaissance weddings in Polish historiography. ${ }^{1}$ The marital union joining together a member of Jagiellonian dynasty with an Italian princess is the subject of many literary sources that see it in terms of a so-called Golden Era. Such sources, along with other narrative, administrative, and diplomatic sources, have enabled historians very thoroughly to document its diplomatic background, the nuptial ceremonies, as well as Bona Sforza's bridal journey from her homeland in southern Italy to Poland. ${ }^{2}$ Yet, there has

\footnotetext{
1 The most significant piece of scholarship remains up to this day Pociecha's monumental, but unfinished work on Bona Sforza: W. Pociecha, Królowa Bona (1494-1557): czasy i ludzie odrodzenia [Queen Bona (1494-1557): The Times and People of the Renaissance], vol. 1, 2, Poznań 1949; other important works, covering Bona's entire life: M. Bogucka, Bona Sforza, Warszawa 2009; G. Cioffari, Bona Sforza: donna del Rinascimento tra Italia e Polonia, Bari 2000; A. Campanella, Bona Sforza. Regina di Polonia, duchessa di Bari, Bari 2008; a comprehensive summary of research is covered in exhibition catalogues: Bona Sforza: regina di Polonia e duchessa di Bari: catalogo della Mostra, vol. 1, eds. M.S. Calò Mariani and G. Dibenedetto, Rome 2000; and Bona Sforza: regina di Polonia e duchessa di Bari: catalogo della Mostra, vol. 2, eds. iidem, Rome 2007. The exhibition took place in 2000, and was presented first in Bari and then in Warsaw.

2 The wedding by proxy took place in Naples on 6 December 1517, and the festivities lasted for several days. Bona and her entourage set off from the Adriatic port of Manfredonia in Italy in February 1518. The journey first went by sea from Italy to Dalmatia and then (from Rijeka) by an overland route through Carniola, Styria,
} 
been no study so far concentrating on an analysis of symbolic values and meaning - expressed by ritual acts—during Bona's journey, since all studies have considered it as a merely geographic transfer, and not in terms of a bridal journey.

The bridal journey, as a scholarly construct, is a relatively new concept in historical writing. The point of this concept is to demonstrate several other functions of the journey besides the mere geographical transfer of a noble bride. Karl-Heinz Spieß distinguishes various functions of a bridal journey: to manifest the power and prestige of the families of the bride and the groom (a representative function), to enable monarchs to communicate with each other (a diplomatic function), and to provide a 'Staatschauspiel,' a state drama by which order and rule are visualized (a festive function). Christiane Coester considers the bridal journey a social act with a hidden symbolic value. ${ }^{3}$ These considerations point to the fact that a bridal journey was not a mere geographical journey, but had deep-rooted implications that may be designated in one word: ritual.

Bona's bridal journey is a particularly suitable case for such an examination, since many and various sources relating to it have survived. The most valuable source concerning Bona's wedding is the description by Justus Ludwik Decjusz. Decjusz starts his account with the death of Barbara Zápolya, Sigismund's first wife. Going through all the diplomatic negotiations concerning Bona's wedding, he provides important evidence about the wedding ceremonies and their guests, along with transcriptions of the speeches and orations. Decjusz' account of Bona's bridal journey is useful from the point of view of the final part, i.e. the encounter of Sigismund and Bona, and the solemn entrance to Kraków. ${ }^{4}$ A detailed description of the journey itself, starting from Bona's farewell to her mother Isabella of Aragon

Austria, Moravia, and Silesia to Poland, where Bona arrived in April. The second wedding and coronation took place in Kraków on April 18.

$3 \quad$ K.-H. Spiess, 'Unterwegs zu einem fremden Ehemann. Brautfahrt und Ehe in europäischen Fürstenhäusern des Spätmittelalters,' in: Fremdheit und Reisen im Mittelalter, eds. I. Erfen, K.-H. Spiess, Stuttgart 1997, pp. 27-28; C. Coester, 'Crossing Boundaries and Traversing Space. The Voyage of the Bride in Early Modern Europe,' in: Moving Elites: Women and Cultural Transfers in the European Court System. Proceedings of an International Workshop (Florence, 12-13 December 2008), eds. G. Calvi, I. Chabot, Florence 2010, p. 10.

4 Jodocus Ludovicus Decius, Diarii et earum quae memoratu digna in splendidissimis, potentissimi Sigismundi Poloniae regis, et serenissimae dominae Bonae, Mediolani, Barique ducis principis Rossani, nuptiis gesta description, Kraków 1518. 
in the Italian port of Manfredonia and ending with wedding ceremonies in Kraków, comes down to us in a poem written by Pathenopeo Suavio, which was the pseudonym of Cola Antonio Carmignano. ${ }^{5}$ Carmignano was a member of Bona's entourage travelling with her from Italy, as well as being her personal treasurer. His account combines realistic features and information with literary techniques and strategies, mostly taken from the genre of wedding poetry (epithalamia). Despite a great number of literary tropes and figures, Carmignano's poem is a valuable source for various material and immaterial aspects of the journey.

As a comparative text for this analysis, I will use the only surviving instructional manual for a bridal journey, the De institutione vivendi by Diomede Carafa. ${ }^{6}$ Although this text was not intended for Bona, but for her great-aunt Beatrice of Aragon (1457-1508), this source is relevant for two reasons: first, both Beatrice and Bona undertook the journey from southern Italy to Central European kingdoms (Beatrice travelled to Hungary) within approximately same period of time (a space of forty years); and second, the author of De institutione, Diomede Carafa (1406/8-1484), reflects on contemporary traditions and customs. Carafa held for a long time a number of military and administrative positions at the Aragonese court in Naples and was, thus, deeply familiar with various practical aspects of the royal court.

This paper will try to examine the symbolic value and messages expressed by the ritual acts performed during Bona's bridal journey. The first question we need to ask is if the bridal journey is in fact a ritual. I will argue that the bridal journey is a rite of passage. Only after unraveling its ritualistic layer, can we shift to an analysis of its particular forms, in this case, the rites of separation and incorporation, and the so-called adventus reginae. What were the meanings and values expressed by these rituals? How were they performed and why?

In order to answer the first question, it is necessary to examine the term 'ritual'. The only definition of ritual accepted by all scholars is the statement by Edmund Leach that there is 'the widest possible

5 N.A. Carmignano, 'Viaggio della s. donna Bona regina da la sua arrivata in Manfredonia andando vero del suo regno de Polonia,' in: Operette del Parthenopeo Suavio (Carmignano), Bari 1535.

6 D. Carafa, De institutione vivendi. Tanítás az életvezetés szabályairól. Emlékeztetô Magyarország fenséges királynéjának [Teaching on Lifestyle. Memorial for the Hungarian Queen], ed. P. Ekler, Budapest 2006. 
disagreement how the word ritual should be understood.7 The problem with establishing a working definition for this term lies in its wide usage, varying from religious, anthropological, sociological, philosophical, and historical fields of study. Each of these disciplines uses this ambiguous term for different purposes, applying different sets of criteria, and employing different methodological approaches.

There have been many attempts to define ritual: for instance, ritual as an analytical category that helps to organize the chaos of human experience; ritual as a set of various characteristics such as framing, formal decision, repeatable form, social or stabilizing function, and change of status; ritual as a prescribed formal behaviour with references to faith; ritual as a system of symbolic communication that is formal, stereotypical and repetitive, and so forth. ${ }^{8}$ Nowadays, an open definition of ritual is accepted as a broad consensus. This means that the proper definition of ritual is one that can yield profitable results in a particular heuristic situation and analysis. Therefore, it depends on the particular study how ritual is defined..$^{9}$

I argue that the bridal journey can be considered a transition ritual or, in other words, a rite of passage. This term is based on Arnold Van Gennep's fundamental work. ${ }^{10} \mathrm{He}$ understands rituals in a religious sense, claiming that there are two spheres, the profane and the sacred, and by crossing the boundary between them one has to pass through a phase or period of passage. This passage takes place during substantial life changes; Van Gennep identifies only three of them, birth, marriage, death, as those involving transition rituals. ${ }^{11}$ Marriage represents the move from the state of childhood to adulthood, from one family to another, from one society to another.

At first glance, the journey of the bride is merely a geographic, not a ritual passage. From the moment of its beginning, the bride is already married, though by proxy, which, according to Church law, was completely valid, and therefore the bride had already ritually passed from obedience to her father to obedience to her husband. However,

7 D. Zupka, Ritual and Symbolic Communication in Medieval Hungary under the Árpád Dynasty (1000-1301), Boston, Leiden 2016, p. 15. Zupka provides a brief introduction to the study of rituals, and a summary of the current state of research.

8 For various cited definitions see J.A.M. Snoek, 'Defining "Rituals", in: Theorizing Rituals: Issues, Topics, Approaches, Concepts, eds. J. Kreinath, J.A.M. Snoek, M. Stausberg, Leiden 2006, pp. 6-7; D. Zupka, Ritual and Symbolic..., pp. 17-19.

9 D. Zupka, Ritual and Symbolic..., p. 17.

10 A. van Gennep, The Rites of Passage, Chicago 1992.

11 Ibidem, p. 126. 
the wedding ceremony is repeated after the bride's arrival at her husband's house. ${ }^{12}$ Her journey is thus something like a 'zero-zone' because, first, the bride is already legally married, but she still has to leave her family and, second, the marriage is still not 'fulfilled' by sexual intercourse. The geographical journey illustrates the symbolic transition which, at least in one moment_- the farewell from the family-is definitely not merely symbolic. Thus, it is reasonable to mark the bridal journey as a significant part of nuptial rituals and as a transition ritual. This is in accordance with van Gennep's ideas since he advanced the concept of rituals as polysemous acts, which means that a single ritual can be interpreted in various ways and, conversely, that one interpretation may be applied to various rituals. ${ }^{13}$

During the passage, one environment, either of the bride or the groom, is weakened, while the other is strengthened. This leads the strengthened environment to compensate for the weakened one, in material or immaterial ways. The material way can be the dowry, gifts, money, lavish ceremonies, or tournaments, whereas verbal or non-verbal expressions may be the immaterial forms of recompense.

The following paragraphs will concentrate on two ritual practices accompanied by various forms of such recompense that are evident in Bona's bridal journey. For heuristic purposes, they are gathered into two groups. The first is the farewell to her mother and the first meeting with her husband; the second is the arrival in cities, the so-called adventus reginae. The main focus of these paragraphs will be on the matter of communication, since current medieval studies deem ritual to be a key vehicle of communication in pre-modern society. ${ }^{14}$ From this perspective, the language, verbal and non-verbal, and the messages of this communication will be examined.

There is, however, a significant pitfall, apparent from the theory advanced by Philippe Buc, who claims that none of the various concepts of ritual used in contemporary medieval studies enjoyed any support in medieval times, and twentieth-century scholars have identified medieval practices as 'rituals' only retrospectively. According to Buc,

12 The statements that a marriage by proxy was legally binding but that it still needed to be repeated may sound contradictory; however, it was a medieval practice to corroborate the marriage by all possible means so that nobody could question its validity. See K.-H. Spiess, 'Unterwegs...,' pp. 25-26.

13 D. Zupka, Ritual and Symbolic..., p. 20.

14 Ibidem. 
there is a great discrepancy between ritual-in-text and ritual-in-performance, and current studies have dealt only with the former. ${ }^{15}$ Some scholars (including Dalewski and Althoff) have tried to find a way out of this scepticism by claiming, for instance, that texts always reflected reality to some extent, since they were embedded in some tradition, or by asserting that these texts were addressed to the audience within the same tradition, and so forth. ${ }^{16}$

For our purposes, Buc's remarks are important in two respects. First, most sources that describe ritual practices during Bona's bridal journey are either of an instructional (Carafa) or a literary character (Carmignano, Decjusz, etc.). As a result, there may be a danger that what they describe was distorted by their rhetorical strategies. Second, although Bona's case abounds in sources, their number is still not sufficient to provide their own independent concepts, and so this case study must depend on earlier ones. The modern concepts I use in my analysis have, thus, an explanatory value for the dispersed pieces of information drawn from the sources, but these concepts may impose a non-existing structure. For instance, applying the category of adventus reginae, a female version of adventus regis, a well-known and developed scheme, to Bona's journey may distort our view of the sources and may make us see reality in line with this scheme even in situations when there is no solid evidence to support it. Thus, in both cases, Buc's remarks demand attention and awareness.

A further remark has to be made concerning terminology, this time on the difference between ritual, rite, and ceremony. This issue is a stumbling block in many studies and articles. Various criteria to distinguish ritual from simple ceremony have been advanced. ${ }^{17}$ Some

15 P. Buc, The Dangers of Ritual. Between Early Medieval Texts and Social Scientific Theory, Princeton, Oxford 2001, pp. 1-12 et passim.

${ }_{16}$ E.g. G. Althoff, 'The Variability of Rituals,' in: Medieval Concepts of the Past. Ritual, Memory, Historiography, eds. G. Althoff, P. Geary, J. Fried, Cambridge 2002, p. 87; Z. Dalewski, Ritual and Politics. Writing the History of a Dynastic Conflict in Medieval Poland, Leiden, Boston 2008, pp. 1-12, 189-194.

17 For instance, Pavlína Rychterová establishes five criteria by which ritual differs from ceremony: ritual must concern a significant life transition (birth, marriage, death); it has to consist of a formal resolution (oath, speech); it must involve a formal act (based on a previous plan); it has to have a social function (reproduction of norms, control); and it must have a transcendental dimension. P. Rychterová, 'Kam s ním? Rituál a ceremonie v medievistice' [What with That? Ritual and Ceremony in Medieval Studies], in: Rituály, Ceremonie a festivity ve střední Evropě 14. a 15. století [Rituals, Ceremonies, and Festivities in Fourteenth and Fifteenth Century Central Europe], eds. M. Nodl, F. Šmahel, Colloquia Mediaevalia Pragensia 12, Praha 2009, pp. 427-432. 
scholars go so far as to allocate all ritual practices to different groupings on the basis of strict criteria among them. In contrast, I operate with the so-called functionalist view that prevails today, although some medievalists do not accept it without criticism. According to this view, it is not important to focus on the differences between these terms, nor is it even feasible to distinguish what is ritual and what is ceremony, because the boundary between them is blurred or non-existent. ${ }^{18}$ Thus, I will use the terms 'ritual', 'rite', and 'ceremony' with no particular difference in meaning.

\section{Farewell and encounter}

Bona's farewell to her mother in Manfredonia is the starting point of the journey. This farewell marks the definitive end of parental authority. From this point forth, Bona passes from parental authority to the authority of her husband, who now takes the place of her father (in Bona's case, her mother) as the ultimate authority responsible for her, and becomes her new father. This is quite obvious in her own words in Carmignano's mouth:

Then, she thanked with astute words

His Majesty, her lord, spouse and father

who treats her with such a great love. ${ }^{19}$

Van Gennep speaks about rites of separation and incorporation. Separation from the bride's natal family during the wedding is followed by a symbolic banishing of things connected with childhood or bachelorhood, for instance, destroying toys, breaking the so-called chain of virginity, etc. On the other hand, there are rites of incorporation by the future family of the bride, that is, by the husband. Such incorporation into the new family may take various forms, varying from a communal meal, drinking from the same pot, sitting on the same chair, and exchanging gifts. All of these strengthen the unifying character of the marriage act. The reason for these rites is to manifest

\footnotetext{
18 D. Zupka, Ritual and Symbolic..., pp. 27-28.

19 'Poi rengratiaua con parole accorte / Sua maiesta, signor, suo sposo e padre / Che cosi caldamente amor li porte.' N.A. Carmignano, 'Viaggio...,' chapter 11.
} 
the withdrawal of the bride from her natal family and her incorporation into the husband's family. ${ }^{20}$

How is this ritual message manifested; in other words, what is the language of these rites? I will first look at the ideal version based on Carafa to show what ideally the farewell to the parents and the encounter with the husband should be like, and then, I will compare this with evidence from Bona's journey.

In Carafa's vision, the farewell to the father takes place twice. The first farewell should happen before the start of the journey, and the second somewhere in the course of it, in the event that the father should want to accompany his daughter for some part of the journey. At the first farewell, the bride is supposed to give a speech containing expressions of regret for having been disobedient, as well thanks and requests for her father's favour in future. Along with that, she should ask on her knees for her father's blessing. ${ }^{21}$ At the second and final farewell to the father, she should ask once again for his benediction and she should try to kiss his hands and feet and not forget to shed tears. ${ }^{22}$ During the first encounter with the husband, Carafa recommends that she get off her horse immediately and clasp her husband's hand..$^{23}$ The rites of separation and incorporation are thus to be expressed both in verbal and non-verbal ways.

When we put together both farewells described by Carafa, it is clear that the moment of separation consisted of verbal features, namely the apologizing-thanksgiving speech and the begging for benediction, and of gestures - the kissing of the father's hands, kneeling, and shedding of tears. The function of these gestures is to emphasize the verbal elements of the ritual. Kneeling is an expression

20 A. van Gennep, The Rites..., pp. 130-132.

21 'Apud dominum regem patrem tuum orationem habeto, in qua eidem immortales gratias ages de omnibus rebus, quas paterna indulgentia in te honorificentissime contulit. Secundo loco precibus summis contendito, ut tui frequentissime velit esse memor cum in tuam gratiam, tum vel maxime ut omnes istic intelligant te ab eo magnifieri et vehementer amari, mox ut tibi clementer parcat, si forte dicto aut facto Maiestatem eius laeseris, id reiiciens cum in ignorantiam, tum in aetatem iuvenilem, quae ad errores et lapsus prona esse consuevit; praeterea genibus nixa rogato, ut omnia tibi fausta dicat, id est, ut christiane loquamur, det tibi benedictionem; nec id aliter quam nixa genibus id abs te peti consentias,' D. Carafa, De institutione..., pp. 16-17.

22 '[...] memento in digressu, ne committas, ut aeque lachrymis confundaris, ut oblivione capiaris iterum supplicandi de benedictione, immo omni ratione experiare pedes et manus deosculandi,' ibidem, p. 20.

${ }_{23}$ '[...] statim ex equo desilito et pro dignitate eum venerato, nullius eidem rei copiam prebens praterquam coniunctionis dextrae,' ibidem, p. 31. 
of reverence and respect in anticipation of grace. The gesture of kissing might express feelings of passion or love, but also greeting, respect, friendship, veneration, peace, or alliance. In this context, the kiss demonstrates the reverence the daughter has for her father's deeds, which are symbolized by his hands, and the utmost veneration she has toward him as the supreme ruler over her fate, which is expressed by her kissing his feet. ${ }^{24}$

Carafa presents the first encounter with the husband, part of the incorporation ritual, solely by non-verbal means. The bride is supposed to immediately get off her horse, which may have the same meaning as kneeling before the father in the separation ritual, that is, to venerate the husband as a new father by clasping his hand. To be more precise, Carafa's advice does not speak directly about the necessity of clasping hands, but merely says that this gesture is allowed. The translation 'clasping hands' slightly disguises the symbolic meaning of the Latin expression coniunctio dextrae. Besides expressing the unifying character of the encounter, and, thus, pointing to incorporation, this Latin expression bears connotations from the Roman tradition. Dextrarum iunctio (or coniunctio) was a part of the Roman marriage ceremony. It is debatable whether the act of clasping hands had a legal status of its own or was solely an artistic and literary expression of marital union, but it is a very frequent motif not only in Roman but also early Christian and medieval art. ${ }^{25}$

Even though Carafa's view was probably based on contemporary practice, it remains in the educative and instructional sphere and does not tell us with certainty that this was the practice or the case. Let us now look at what is described in the sources touching on Bona's voyage. In contrast to Carafa's description of acts accompanying the farewell

24 R. Šimůnek, 'Rituály, ceremoniály a symbolická Komunikace v životě české středověké šlechty' [Rituals, Ceremonials and Symbolical Communication in the Life of Medieval Bohemian Nobility], in: Slavnosti, ceremonie a rituály v pozdním středověku [Festivities, Ceremonies and Rituals in Late Middle Ages], eds. M. Nodl, F. Šmahel, Prague 2014, pp. 291-293. For the symbolism of the kiss, see W. Frijhoff, 'The Kiss Sacred and Profane: Reflections on a Cross-Cultural Confrontation,' in: A Cultural History of Gesture. From Antiquity to the Present Day, eds. J. Bremmer, H. Roodenburg, Ithaca 1992, pp. 210-236.

25 K.K. Hersch, The Roman Wedding. Ritual and Meaning in Antiquity, New York 2010, pp. 199-206. Hersch challenges the scholarly accepted theory that dextrarum iunctio was the condition sine qua non of a Roman wedding, and offering evidence from Roman literary works, she claims that the handclasp might have been just a metaphor (literary or artistic) of marital union. 
and the first encounter, which perfectly fit Van Gennep's concept of separation and incorporation, Bona's case is different.

Bona's farewell from her mother, since her father was already deceased, is described in greater detail in the first chapter of Carmignano's poem. In it, the farewell concentrates solely on the mother's and daughter's grief when bidding the final goodbye to each other. A dominant motif is the weeping, which is stretched to a cosmic level. Although a resemblance with Carafa's advice 'to shed tears' can be seen, the gesture of crying has a radically opposite function in Bona's case-to put in rhetorical categories a heartbreaking separation between mother and daughter. Bona, her mother, the entire entourage, and even surrounding nature cry. 'I have never seen such a day of weeping, the entire world was full of laments. ${ }^{.26}$ Carmignano alludes to famous separations in literature, Aeneas from Dido, Achilles from Deidamia, Theseus from Ariadne, as well as examples of the sorrows of lovers such as Pompey and Cornelia or Pyramus and Thisbe. All of this is meant to describe the farewell as a sorrowful act, not only for mother and daughter, but for all nature. This works well as a literary device, but does not provide us with any precise information about the ritual practices that actually accompanied Bona's separation from her mother.

Another source tells us that the procedure Carafa describes was partially followed. In his description of Italy from $1530,{ }^{27}$ Leandro Alberti recounts that in Manfredonia there was still standing a stone staircase that Bona used to embark on the ship, and that there, with tears in her eyes, she asked her mother for pardon and for her blessing, and that this is incised in the stone. ${ }^{28}$ More than mere accordance

26 N.A. Carmignano, 'Viaggio...,' chapter 1.

27 Leandro Alberti (1479-1559) a Dominican friar of Florentine origin, was a humanist historian, philosopher and theologian. He edited some lives of Dominican saints and wrote histories of Bologna and Venice. His most famous work is Description of the Whole of Italy (Descrittione di tutta Italia), which tries to complete and update Flavio Biondo's cosmography of Italy, but lacks the critical approach of the latter text. A.L. Redigonda, A. Leandro, Dizionario Biografico Degli Italiani, 1960, http://www. treccani.it/enciclopedia/leandro-alberti_(Dizionario-Biografico)/ [accessed: 25.09.2017].

28 'Fuori la Citta al lito si vede un'artificioso Molo per sicurezza delle naui che quiui vengono con le mercantio. Quiui si veggiono alquanti scaglioni di pierra per scendere dal Molo alle naui, in vno de i quali, sono formato le forme de i piedi de la Signora Buona gia figliuola di Giouan Galeazzo Sforza Duca di Melano \& de Isabella di Ragona sua consorte Duchessa di Barri (oue si fermo douendo scender alle naui per passare il mare Adriatico, \& andare in Polonia per sonsorte di Sigismondo Re) per chiedere perdono $\&$ buona licentia con lagrime alla sua madre. Et oltra le dette forme, cosi e scriito nel 
with Carafa, this text shows the contemporary use of ritual practice during the departure of the bride and points to the fact that it was still remembered many decades later.

Let us now turn to the counterpart of the farewell-the first encounter with the husband at the end of the journey. Unlike the farewell, the sources for it are reversed: Carafa speaks very little about it, whereas Carmignano and Decjusz describe it very vividly.

In Carmignano's account, the encounter took place outside the walls of Kraków. King Sigismund was waiting in front of a red pavilion, surrounded by many bishops, dukes, noblemen, and ambassadors, and up to two hundred soldiers dressed in white uniforms with banners of St George. Bona approached accompanied by thousands of horses, which the king had sent her for this purpose the day before. She immediately got off her horse, knelt before the king, and kissed his hands. The king replied by embracing her firmly. ${ }^{29}$ Decjusz confirms this account and adds that they clasped hands. ${ }^{30}$ The resemblance with Carafa is striking, though he would perhaps protest against the king's embrace, but, still, this gesture does manifest the incorporation of the bride.

The incorporation moment is heightened by a verbal element. The archbishop of Gniezno, the highest ecclesiastic authority of the kingdom, welcomed the new queen. Carmignano sums up this speech in a few words. Reportedly, it was very dignified and gracious; in it, the archbishop entrusted the queen with the entire kingdom and its people. ${ }^{31}$ Decjusz reports this speech in full. The archbishop entrusted the queen with the kingdom and all subordinates, as Carmignano states, but that was not the main point of the speech. The main focus lay on matters of marriage in relation to dynastic motives: Bona and Sigismund both came from magnificent families and had

sasso. Qui si fermo la Reina di Polonia, quando chiese venia \& licentia a Madamma Isabella sua madre Duchessa di Melano \& di Barri,' Leandro Alberti, Descrittione di tutta Italia di F. Leandro Alberti Bolognese, Venice 1551, p. 203v.

29 'Piu de sei milia dico a non mentire / Li apede in dece di contra non uali / Se pur non uuoi del conto preterire [...] Essendo poi concesso peruenire / Doue il Re Sigismondo dimoraua / Vi era un bel pian quanto si possa dire / Iui di rosso un pauiglion ui staua / Col Re, Vescoui, Duchi, e gran Signori [...] Atorno ui eran ben ducento armati / Dal Re uestiti de bianca librera [...] Smontata la Regina non for tarde [...] E lei chinata in lui senza alter scorte / Le man li basa, e se ricessa alquanto / El Re la abraccia, e a se la strense forte,' N.A. Carmignano, 'Viaggio..., chapters 12-13.

30 Jodocus Ludovicus Decius, Diarii..., p. [d2r].

31 N.A. Carmignano, 'Viaggio...,' chapter 13. 
glorious predecessors, so it was right for them to join in holy matrimony and bear such illustrious offspring as themselves. The words of the archbishop welcomed the queen in the hope that she could give the king the only thing he lacked-an heir:

[Sigismund] lacks nothing, nothing except a successor. Now, we put all our hope in you. Our kingdom does not ask you for anything else than to bring out (a child) who would express and represent his parent, the king. If there is a need, we will be even more studious and obedient. ${ }^{32}$

Therefore, in the archbishop's words, the kingdom accepts and pays homage to the queen because of her only task, to bear children to the king. The archbishop ensures the assembly that Bona is able to comply with this task because of her illustrious pedigree, her personal virtues and beauty, as well as her name. 'Bona' means 'good' in Latin, so the archbishop uses her name to see this as good sign and as a portent of success. ${ }^{33}$

Bona's secretary responded on her behalf, but unfortunately this speech has not been preserved. Decjusz was unable to hear it, most likely because the encounter was announced by a 'terribili sonitu' of canons, so the stars could hear too. He does, however, mention that this speech was quite brief and that after it clergymen and noblemen kissed Bona's hand. ${ }^{34}$ All present members of Bona's new 'family' thus confirmed the archbishop's speech. By this welcome, the queen was accepted into the community and the journey was completed. The wedding ceremonies in Kraków could now begin.

${ }_{32}$ Venit igitur tua Sacratis. Maie. ad eum Sponsum, quem iam praesentem intueri possi, cuius dextrae iam tuam iunxisti. Accipe hunc iucunde \& placide cum quo regnum amplissimum magnaque dominie sis acceptura. Nihil sibi deest, nisi filius successor. Nunc in te omnis spes nostra sita est. Non aliud a te magis res publica nostra expostulate, quam ut nobis talem producas, qui parentem exprimere, \& representare possit. Nos uero omnes subditi sui, tanto studiosiores, \& obsequentiores tibi erimus, quanto magis reuereri opportebit, \& parentem qui regnat, \& filium qui in regno successor erit,' Jodocus Ludovicus Decius, Diarii..., p. [d2r-v].

33 'Et sicut nomine BONA es, sic te semper nobis bonam, gratiosam, clementemque praebeas, omnique benignitate prosequere,'ibidem, p. [d2v].

${ }_{34}$ 'Interim ad machinarum magistros nunciatum est, qui terribili sonitu hunc congressum ad astra usque nunciauerunt. Dicta oration Ludouicus Secretarius uir facundus \& doctus Reginae uerbis respondit admodum breuiter, quae tunc audire, necque habere potui... Regiaque osculate manu ad salutationem Regiae sponsae, nostril pro dignitate accesserunt [...],' ibidem. 
A good comparative, but much shorter example presents the first encounter of the Sigismund's parents-King Casimir IV (1427-1492) with his future bride-to-be Elisabeth of Habsburg (1436-1505) in 1454. The king went to meet his bride on a Saturday afternoon, together with his mother Sophia, many bishops, and noblemen. All of them, especially the king, were lavishly dressed in purple with golden ornaments; the equipment of the king's horse was made from velvet decorated with golden embroidery, which was reckoned at forty-thousand florins. However, the meeting did not last long, as Długosz points out, the bad weather did not favour the royal meeting because it was raining heavily the entire day: all dresses were drenched and the procession could not hold together because everybody flew to hide themselves from the rain. ${ }^{35}$

Despite the brevity of the event, we can see traces of the ritual behavior similar to Bona and Sigismund's first encounter: Casimir accepted his future bride with a 'cheerful and happy face,' Elisabeth and Sofia (the queen mother) shook hands (dextris datis), and then they ascended the same carriage, in which they entered Kraków. These gestures, although briefly described, express the same incorporation of the new bride into the new royal family. Moreover, in comparison to Sigismund and Bona's encounter, in this case, the queen mother plays a significant role in the incorporating ritual: she symbolically joins her hand with that of the new queen-to-be and then rides with her in one carriage. That shows that the queen mother had a very significant role in accepting the king's new bride, a role that however could not be performed during Sigismund and Bona's encounter. ${ }^{36}$

In summary, the beginning and the end of the bridal journey were accompanied by various verbal and non-verbal ritual practices. As the queen passed from paternal to marital authority she had to express reverence towards each of them by words and gestures of veneration, such as kneeling, kissing, or tears. These expressions were to represent her separation from previous circles and her incorporation into new ones.

35 J. Długosz, Annales seu cronicae incliti regni Poloniae. Liber duodecimus 1445-1461, Kraków 2003, pp. 178-179.

36 Sigismund's mother Elisabeth died in 1505. 


\section{Adventus reginae}

Adventus regis, or the entry of the king, is a well-known category in historical writing. It is characterized as an elaborated set of rituals that served to manifest, visualize, and represent the royal power and the ruler's sovereignty over a city. ${ }^{37}$ If this is so, can we talk about adventus reginae, the entry of the queen, as a ritual?

There is plenty of evidence from Bona's journey depicting ritual practices during her entries into cities. Yet the queen-at present, only a bride traveling to her husband — cannot manifest her power over a city since she does not possess it. This is especially true when she enters cities that do not belong to her husband's kingdom. In is this case, the message of the adventus reginae ritual must be slightly different. I will argue that rituals on Bona's adventus were to manifest the prestige of her husband, King Sigismund, as well as of his allies, especially Emperor Maximilian and King Vladislaus II of Hungary and Bohemia, since she passed through areas that belonged to these two sovereigns. Let us remember that the marital union of Sigismund and Bona was an outcome of Emperor Maximilian's masterly diplomacy with the goal of creating a powerful Habsburg-Jagellonian alliance, and that it had resulted in a mutual-succession treaty and the First Congress of Vienna only a few years earlier. ${ }^{38}$

According to G. J. Schenk, an ideal version of royal entry had five parts: preparation, a meeting at some distance from a city, a solemn welcome at the city gate, a procession through the city, and a final liturgy. This structure, however, is nothing more than a scholarly construct. Generally, in written sources from the Middle Ages, there are few references to royal entries and, when present, these seem to be concerned with only two parts of Schenk's ideal version: a solemn welcome and a procession. The 'ideal' version relies on the practice from the Early Modern period and assumes, retrospectively, the continued presence of this tradition in earlier centuries. To what extent Schenk's ideal scheme applies to every entry of every king into every

37 For what is probably the most crucial synthesis of the issue, see G.J. Schenk, Zeremoniell und Politik. Herrschereinzüge im spätmittelalterlichen Reich, Köln 2003.

38 The most recent study of Maximillian's diplomacy is: E. Frimmová, 'Diplomatické rokovania na začiatku 16.storočia' [Diplomatic negatiations in the early sixteenth century], in: Od symbolu k slovu. Podoby stredovekej komunikácie [From symbol to word. Forms of medieval communication], ed. M. Hlavačková, Bratislava 2016, pp. 53-69. 
city is debatable, not only because of the scarcity of sources but simply for practical reasons.

As an example of the traditional royal adventus, the entry of Emperor Sigismund of Luxembourg (1368-1437) and his spouse Barbara of Celje (1392-1451) into Constance in 1414, depicted by burgher Ulrich von Richental, is often quoted. Since Carafa does not describe in detail the entry into a city, we might use Richental as a point of reference, especially since he does speak about the role of the queen in such entries.

The arrival of Sigismund of Luxembourg and Barbara of Celje in Constance took place on Christmas Eve. The message that the king was approaching arrived in the city a few days before, but nobody knew where exactly the king was. An hour before midnight on Christmas Eve, a new message arrived that the king and his entire entourage were in Überlingen, a small city close to Constance. Sigismund sent a message to the pope asking him to suspend the Christmas Eve liturgy until his arrival. Meanwhile, preparations began in the city and the city hall was prepared to welcome the king. Two hours after midnight Sigismund and his entourage left Überlingen by ship and arrived at the city hall in Constance. They stayed there for a while, warming themselves up, and then proceeded to the cathedral for the Christmas Eve liturgy. On the way there, Sigismund and Barbara walked separately under two baldachins that were given to them by burghers. The procession was followed by such a large number of people carrying candles that it seemed as if a house were burning. ${ }^{39}$ The same procession with baldachins took place when Sigismund and Barbara departed from the city in July $1415 .{ }^{40}$ Although the queen's role was purely supplementary, the fact that she processed under her own baldachin suggests that her role was important in showing her husband's power and prestige.

This account also shows how difficult it is to fit the evidence from sources to the ideal scheme of the adventus. This is the case to an even greater extent in Bona's journey. Carmignano speaks about entries into many cities, with various degrees of pomp and solemnity depending on the region and the prominence of the city. In some cities, he mentions only that Bona was welcomed by bombarde and artiglierie (in Rijeka, Ljubljana, Leibnitz), in others he notes the various plays

39 U. Richental, Kostnická kronika [Chronicle of the Council of Constance], eds. F. Šmahel and D. Dvořáková, trans. M. Papsová, Budmerice 2009, pp. 105-107.

40 Ibidem, pp. 184-185. 
and festivities that were mounted (in Kamnik, Olomouc). In some cities, the entourage was received with welcoming speeches and gifts. The most common gift, given to Bona at least three times, was a coppa d'auro, a golden goblet (in Vienna, Oświęcim, Tenczynek). ${ }^{41}$

Bona's retinue was often escorted by a local contingent of horsemen (e.g. in Maribor, Olomouc). The function of this escort might have been not only representative, but protective too. Although the sources do not document this purpose, in the account from Anne de Foix's bridal journey, taking place twelve years before Bona's journey, in parts of Slavonia the queen was escorted by seven or eight thousand soldiers because of the danger posed by the Turks. ${ }^{42}$

The pomp and sumptuousness of entries grew gradually after passing the borders of Poland. On the limits of the kingdom, Captain Giordano and an equestrian squad were waiting to welcome Bona. The horsemen were dressed in golden clothes, carrying a great number of banners. The captain's wife and various other women also paid homage and welcomed the queen. Bona got out of her carriage and expressed her gratitude to Sigismund, her spouse, on whose behalf they had come to greet her. ${ }^{43} \mathrm{~A}$ similar scenario occurred in the case of Elisabeth of Habsburg in 1454. Elisabeth stopped for two days in Cieszyn where she was endowed with the 'power of Polish barons' sent to welcome her by Casimir. ${ }^{44}$ These welcoming squads of noblemen clearly were the pre-phase of the incorporation rites of the new bride and queen, along with being a strong manifestation of the groom's power and wealth.

The entry into Kraków, the final destination of Bona's journey, was of major significance. An important part of it, the first encounter of Bona and Sigismund, has already been discussed in the previous subchapter. Let us resume the chain of events where we left it. After the speech by the archbishop of Gniezno, the response of Bona's secretary, and the respect paid to Bona by the noblemen, a monumental procession was formed. It consisted of bishops, noblemen, ambassadors of foreign princes, as well as numerous guests and their retinues.

$41 \quad$ N.A. Carmignano, 'Viaggio...,' chapters 3-11.

42 Reneszánsz utazás. Anna királyné 1502-es fogadtatásának ünnepségei Észak-Itáliában és Magyarországon [The Renaissance Journey. The Welcome Feasts of the Queen Anne in Northern Italy and Hungary in 1502], ed. A. Györkös, Máriabesnyő 2016 (Scriptores Rerum Hungaricarum, 9), p. 132.

43 N.A. Carmignano, 'Viaggio...,' chapter 11.

44 J. Długosz, Annales..., p. 177. 
Decjusz and Carmignano put the number of horses in the procession at six thousand. The royal couple rode on horses; near them rode the most important guests: the margrave of Kazimierz, Cardinal Ippolito d'Este, Duchess Anna of Mazovia, and the ambassadors of Emperor Maximilian. ${ }^{45}$

When they reached the university, the royal couple heard another speech, this time given by Stanislaw Biel, Rector of the university. He also pointed out Bona's excellent family and virtues that can enhance the splendour of the kingdom of Poland. After that, the procession continued to the outskirts of the city where a hastilude took place. From there, the procession went its way through the city to the castle of Wawel. The streets as well as the citizens were lavishly decorated, and the road from the city gate to the castle was lined with men-inarms. The sound of cannons and the light of torches accompanied the procession since the sun was already setting. ${ }^{46}$

In comparison with Sigismund and Barbara's entry into Constance, Bona's entry into Kraków was much more elaborate. The same applies to the entry of Elisabeth of Habsburg in 1454, which was, as we saw, hampered by the bad weather. Nevertheless, the procession was accompanied by the blasts of trumpets and concluded by a welcome in front of the Wawel Cathedral and a solemn liturgy. ${ }^{47}$ The fact that Bona's entry into Kraków, along with other such entries along the journey, was a part of nuptial ceremonies and, thus, in some sense, had a unique character, ensured that it was better described, and in greater detail in the sources that refer to it. Words, ornaments, gifts, colors, sounds, and gestures of the adventus, all of this was intended to manifest the magnificence of the royal wedding, and the power and prestige of King Sigimund. But is there any special reason why Bona was so lavishly welcomed outside the kingdom of her husband?

The speech by Ludwig Restio, a scholar at the university of Vienna, may provide some hints. He welcomed Bona to Vienna on behalf of the university. In his oration, Restio focuses not only on Bona's and Sigismund's excellent virtues and families, as we have previously seen, but also on Emperor Maximilian's qualities. Restio remarks how necessary the emperor's contribution was in arranging the wedding and how beneficial it would be for the whole of Christianity. According

45 For a detailed list of guests and an account of the procession, see Jodocus Ludovicus Decius, Diarii..., pp. [d3r-e2r].

46 Ibidem, p. [e3r].

47 J. Długosz, Annales..., p. 179. 
to Restio, Bona's prominent ancestors, such as Francesco Sforza, may be compared to imperial figures in terms of glory and deeds. In addition, Bona's spouse, King Sigismund, can be compared only to the emperor himself. ${ }^{48}$ Therefore, the leg of Bona's journey through the emperor's territories was celebrated in order to demonstrate the emperor's political genius in arranging this wedding.

To summarize my discussion, the bridal journey was not merely the physical movement of the bride from her country of origin to her husband's country, but it embodied a significant ritual layer that points to the fact that it was a part of the marriage of two royal houses. Thus, the journey was meant to manifest the bride's rite of passage from being an unremarkable woman to one whose task was to bear a future king. This had to be expressed by a number of ritual practices that visualized the symbolic value of marriage, as well as the power and richness of the families involved. The best-documented rites of this kind in the sources concerning Bona's journey are those of her separation and incorporation as a bride and queen, and her entries into different cities on her way to Poland. The separation and incorporation that take place in the beginning and the end of the journey express Bona's transition from an old authority, that of her mother, to a new one, that of her husband. In addition, by the act of incorporation she is symbolically received not only into her husband's family, but also as queen of the entire kingdom. The prominence of the royal bond is evidenced in various ways; the most common one could be called the adventus reginae. This elaborate set of rituals, performed in different partial forms during Bona's journey and eventually in an outstanding way on her final entrance into Kraków, displayed the prestige of her husband King Sigismund, as well as the diplomatic genius of Emperor Maximilian, who had negotiated the marriage. Each of the ritual practices was like a brush stroke on a painting portraying the magnificence of the royal wedding, its procreative dynastic goals, and the prominence of the families uniting in one couple.

48 L. Restio, Oratio ad illustrissimam Bonam Sfortiam [...] 14 Kalen[dis] Aprilis anno 1518 in eius adventu Universitatis Viennensis nomine in magno tum procerum, tum eruditorum co[n]fessu habita, Vienna 1518, pp. [a3r-v, a5r]. 


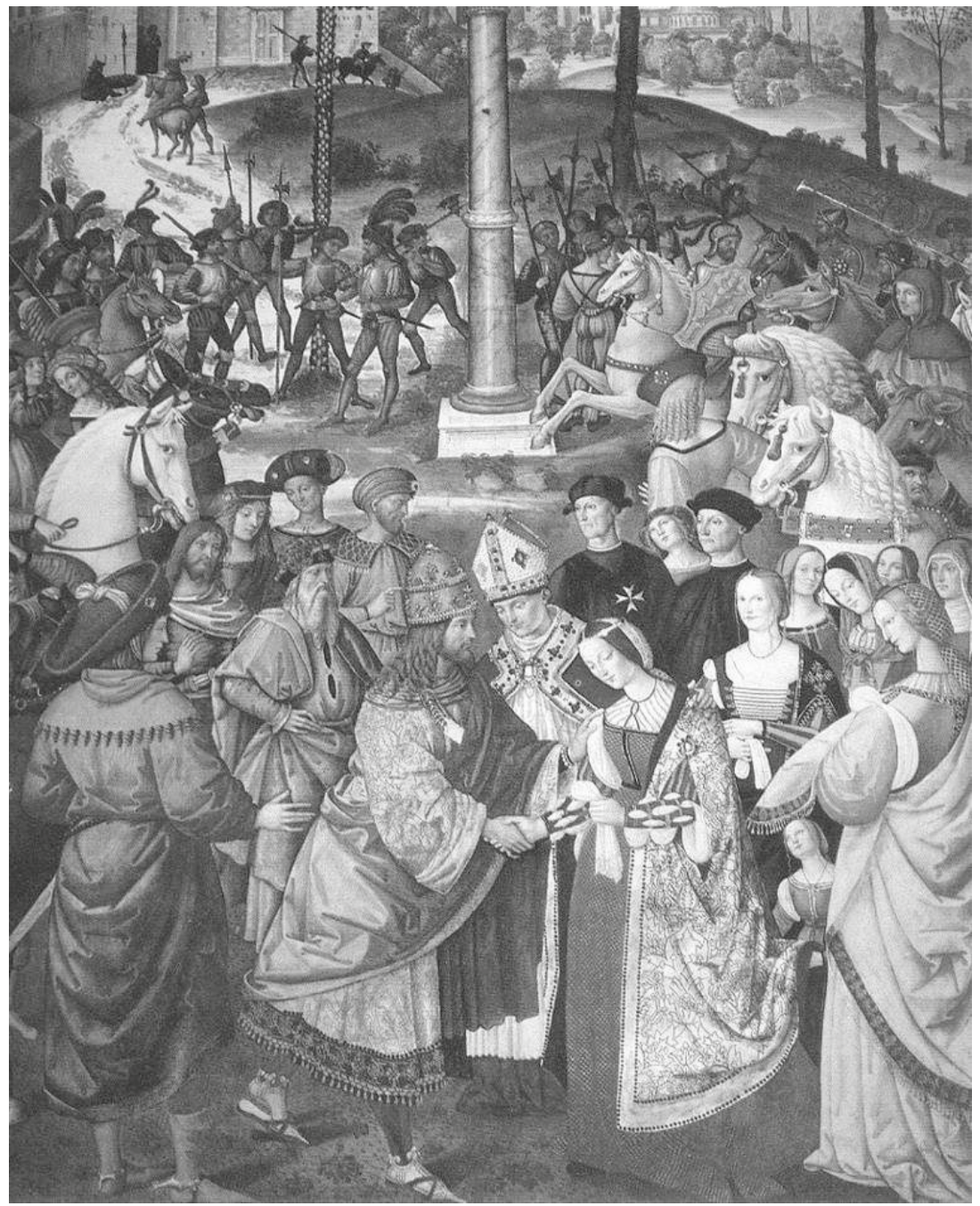

Fig. 1. Pinturicchio, The Encounter of Frederick III and Eleanor of Portugal (Cathedral of Siena, Piccolomini Library). We can see the dextrarum iunctio of the bride and groom as Carafa and the sources in Bona's case describe it; source: https://commons.wikimedia.org/wiki/File:2016_Siena_-_Piccolomini_ Library_01.jpg [accessed: 25.09.2017] 


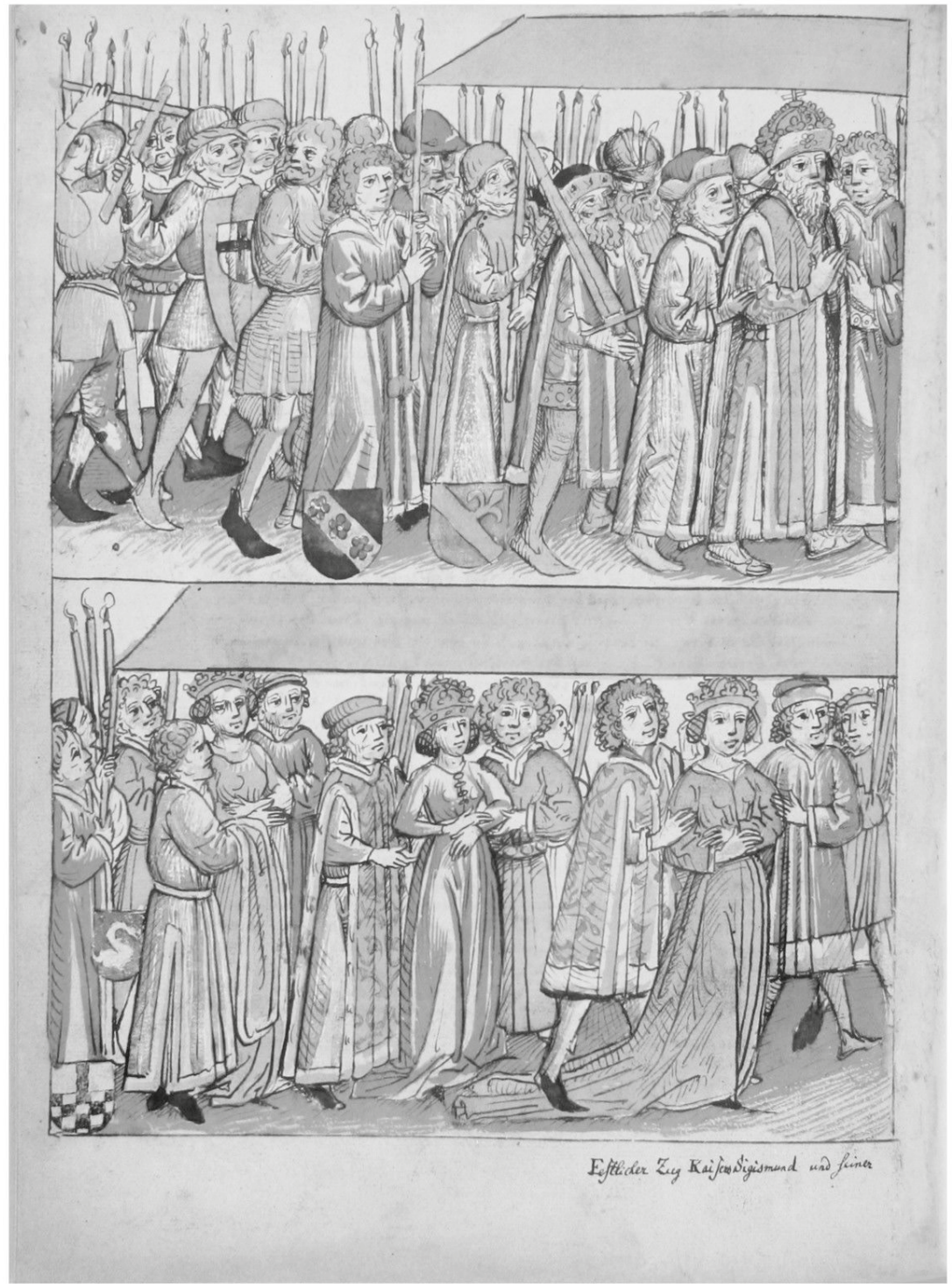

Fig. 2. The procession of Sigismund of Luxembourg and Barbara of Celje into Constance (Ulrich Richental's Council Chronicle); source: https:// commons.wikimedia.org/wiki/File:Konstanzer_Richental_Chronik_Bilder_ vom_Weihnachtsgottesdienst,_Prozession_zum_M\%C3\%BCnster_19v.jpg [accessed: 25.09.2017] 